\title{
Superoxide production by Crohn's disease neutrophils
}

\author{
F T Curran, R N Allan, M R B Keighley
}

\begin{abstract}
Neutrophil superoxide anion production was measured in healthy subjects and in patients with quiescent and active Crohn's disease using superoxide dismutase inhibitable cytochrome $\mathbf{C}$ reduction. Three stimuli were used: phorbol 12-myristate 13-acetate (PMA1), phorbol 20-oxo-20-deoxy 12-myristate 13-acetate (PMA2), and Candida albicans in serum. Normal neutrophils produced significantly more superoxide anion than Crohn's disease neutrophils with both PMAl (mean (SD) 9.6 $(2.2)$ v $8.6(1.8) \mathrm{nmol} / 10^{6}$ cells $/ 5$ minutes, $\mathrm{p}=0.04)$ and PMA2 $(1.8(0.8)$ v $0.8(0.77)$ nmol $/ 10^{6}$ cells $/ 5$ minutes, $\left.p=0.00004\right)$. With $C$ albicans in serum, normal and Crohn's disease neutrophils produced similar amounts of superoxide anion (4.4 (1.5) $v 4.3(1.7)$ nmol $/ 10^{6}$ cells $/ 30$ minutes, not significant). Results were independent of disease activity. Superoxide anion production by PMAstimulated Crohn's disease neutrophils is significantly lower than by normal neutrophils.
\end{abstract}

Although neutrophil metabolism is based largely on anaerobic glycolysis an increase in oxygen consumption can be shown during phagocytosis. ${ }^{1-3}$ This respiratory burst is necessary for the subsequent killing of micro-organisms; it coincides with the activation of the oxidase enzyme system which transfers a single electron from reduced nicotinamide adenine dinucleotide to the oxygen molecules, forming superoxide anion (the NADPH oxidase system). ${ }^{4}$ Superoxide anion production was measured to determine whether it could be the cause of the impaired killing ability by neutrophils in Crohn's disease, which we have previously reported. ${ }^{5}$

Details of healthy subjects and patients with Crohn's disease

\begin{tabular}{|c|c|c|}
\hline & Healthy subjects & Crohn's disease \\
\hline \multicolumn{3}{|c|}{ Superoxide production with PMAl: } \\
\hline No & & \multirow{5}{*}{$\begin{array}{l}25 \\
42(19) \\
9 \mathrm{M}: 16 \mathrm{~F} \\
\text { Quiescent } 15 \\
\text { Active } 10 \\
4\end{array}$} \\
\hline Mean (SD) age (years) & $45(14)$ & \\
\hline Sex & $8 \mathrm{M}: 7 \mathrm{~F}$ & \\
\hline Disease activity & - & \\
\hline \multirow{2}{*}{\multicolumn{3}{|c|}{$\begin{array}{l}\text { Steroid treatment } \\
\text { Superoxide production with } P \overline{M A 2}\end{array}$}} \\
\hline & & \\
\hline $\begin{array}{l}\text { No } \\
\text { Mean (SD) age (years) }\end{array}$ & $\begin{array}{l}15 \\
52(17)\end{array}$ & \multirow{3}{*}{$\begin{array}{l}25 \\
40(16) \\
10 \mathrm{M}: 15 \mathrm{~F} \\
\text { Quiescent } 15 \\
\text { Active } 10\end{array}$} \\
\hline Sex & $7 \mathrm{M}: 8 \mathrm{~F}$ & \\
\hline Disease activity & - & \\
\hline \multirow{2}{*}{\multicolumn{3}{|c|}{ Superoxide production with $\mathrm{C}$ albicans in serum: }} \\
\hline & & \\
\hline & & \multirow{5}{*}{$\begin{array}{l}25 \\
43(17) \\
9 \mathrm{M}: 16 \mathrm{~F} \\
\text { Quiescent } 14 \\
\text { Active } 11 \\
4\end{array}$} \\
\hline Mean (SD) age (years) & $42(15)$ & \\
\hline $\begin{array}{l}\text { Sex } \\
\text { Disease activity }\end{array}$ & 9M:6F & \\
\hline & & \\
\hline Steroid treatment & - & \\
\hline
\end{tabular}

Superoxide production was determined by the spectrophotometric measurement of superoxide dismutase inhibitable cytochrome $\mathrm{C}$ reduction. Superoxide reduces cytochrome $\mathrm{C}^{6}$ but other electron donors are also produced during phagocytosis which can similarly reduce cytochrome C. Superoxide dismutase is a copper-containing enzyme occurring in red and white blood cells. It destroys superoxide by catalysing its conversion to oxygen and hydrogen peroxide. In vivo the enzyme prevents local tissue damage by toxic radicals. ${ }^{7}$ The use of superoxide dismutase in the assay makes it specific for superoxide since any remaining cytochrome $\mathrm{C}$ reduction must be the result of other electron donor systems and can be deducted from assays performed simultaneously without superoxide dismutase.

\section{Methods}

Fifteen healthy volunteers and 25 patients with Crohn's disease were studied using three different stimuli of phagocytosis. Patient details are summarised in the Table. Disease activity was assessed using the method of Harvey and Bradshaw, ${ }^{8}$ and patients taking sulphasalazine were excluded from the study.

\section{PREPARATION OF NEUTROPHILS}

Neutrophils were isolated from fresh venous blood using discontinuous density gradients of Percoll (Pharmacia) as follows. An iso-osmotic stock solution of Percoll was made by adding 1 part $1.5 \mathrm{M}$ saline to 9 parts Percoll (resulting density $1 \cdot 123 \mathrm{~g} / \mathrm{ml}$ ). Stock Percoll was further diluted with $0.15 \mathrm{M}$ saline to densities of 1.070 $\mathrm{g} / \mathrm{ml}^{9}$ and $1.097 \mathrm{~g} / \mathrm{ml}^{10}$ for the separation of white cells. Into a sterile universal container were placed $6 \mathrm{ml}$ Percoll of density $1.097 \mathrm{~g} / \mathrm{ml}$, then 4 ml Percoll of density $1.070 \mathrm{~g} / \mathrm{ml}$ was carefully layered on top taking care not to cause mixing at the interphase. Five $\mathrm{ml}$ of heparinised blood was diluted with an equal volume of $0.15 \mathrm{M}$ saline and carefully layered on top of the Percoll in the same way. The tube was centrifuged at $200 \mathrm{~g}$ for 25 minutes, resulting in the isopycnic banding of cells at the relevant interphases; granulocytes were suspended between the two layers of Percoll. They were removed with a pipette and washed twice in Dulbecco's B phosphate buffered saline, centrifuging at $1500 \mathrm{~g}$ for 10 minutes after each wash. Any contaminating erythrocytes were lysed by hypotonic shock treatment by resuspending the cells in trisammonium chloride for 10 minutes before the second wash. Neutrophils were counted in an improved Neubauer chamber and resuspended in PBS at a concentration of $5 \times 10^{6}$ cells per $\mathrm{ml}$. All neutrophil suspensions were at least $95 \%$
General Hospital, Birmingham F T Curran

M R B Keighley

Correspondence to: Mr F T Curran, Queen Elizabeth Hospital, Edgbaston, Birmingham B15 2TH.

Accepted for publication 1 June 1990 


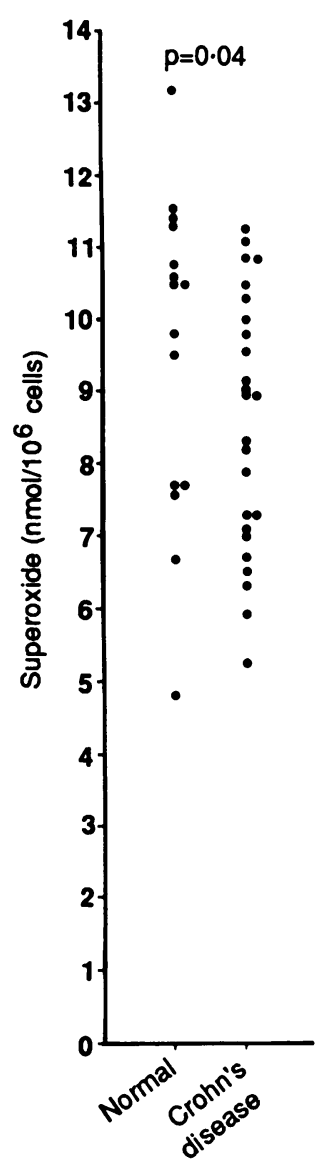

Phorbol 12-myristate 13-acetate
Phorbol 20-0xo-20-deoxy 12-myristate 13-acetate
NS
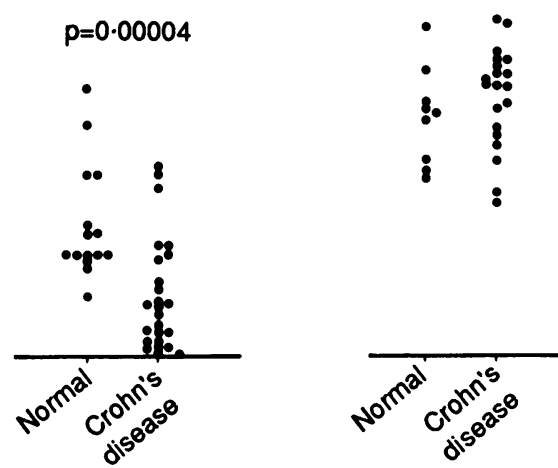

Candida albicans

(incubation time 30 minutes) (incubation time 5 minutes)

Figure 1: Neutrophil superoxide anion production.

pure, and their viability was $98 \%$ when assessed by trypan blue exclusion tests. ${ }^{11}$

\section{PREPARATION OF ORGANISMS}

Candida albicans from the same source was used in all experiments. The organisms were isolated from the faeces of a healthy woman receiving no medication and were maintained in stock culture on a slope of malt extract agar (Oxoid) at room temperature. When required, a sample of the organisms was inoculated into approximately 50 $\mathrm{ml}$ Sabouraud liquid medium (Oxoid) and grown to a stationary phase for three to five days at $30^{\circ} \mathrm{C}$. They were washed twice in PBS, centrifuged at $1500 \mathrm{~g}$ for 10 minutes after each wash, counted in an improved Neubauer haemocytometer, and suspended in PBS at a concentration of $10^{7}$ organisms per ml. Freshly cultured organisms were used in all tests.

MEASUREMENT OF SUPEROXIDE PRODUCTION A $1.4 \mathrm{ml}$ neutrophil suspension $\left(7 \times 10^{6}\right.$ cells $)$ was placed in each of two tubes and $30 \mu \mathrm{g}$ superoxide dismutase in $10 \mu \mathrm{l}$ PBS was added to one tube. Both tubes were incubated at $37^{\circ} \mathrm{C}$ in a water bath for two minutes. To each tube was added 3 mg horse heart cytochrome $\mathrm{C}$ type VI (Sigma) in $0.1 \mathrm{ml}$ PBS, followed immediately by a stimulus of phagocytosis. The stimuli used were: (a) $5 \mu \mathrm{g}$
PMAl in $1.5 \mathrm{ml} \mathrm{PBS}$; (b) $5 \mu \mathrm{g}$ PMA2 in $1.5 \mathrm{ml}$ PBS; (c) $10^{7} \mathrm{C}$ albicans in $1 \mathrm{ml} \mathrm{PBS}+0.5 \mathrm{ml}$ fresh normal serum. In addition, serum stimulated superoxide release - that is, without Candida was assessed on two occasions, once with normal neutrophils and once with Crohn's disease neutrophils.

After mixing, $1.5 \mathrm{ml}$ from each tube was reserved in melting ice (time 0 ) and the remaining $1.5 \mathrm{ml}$ incubated at $37^{\circ} \mathrm{C}$ in a water bath for five minutes with PMA or 30 minutes with Candida. The reaction was stopped by placing the incubated tubes in melting ice. All four tubes were centrifuged at $4^{\circ} \mathrm{C}$ for 20 minutes to remove cells and the absorbances of the supernatants read in a single beam spectrophotometer (Cecil) using the unincubated (time 0 ) samples as blank. Thus for each assay two results were obtained, one with superoxide dismutase added and one without it.

Superoxide anion production was calculated from the absorbances using the formula:

\section{A $\times$ reaction volume $\overline{\text { E } \times \text { number of cells } \times \text { light path }}$}

where $\mathrm{A}=$ (absorbance at $550 \mathrm{~nm}$ without superoxide dismutase) - (absorbance at $550 \mathrm{~nm}$ with superoxide dismutase), reaction volume $=1.5 \mathrm{ml}$, $\mathrm{E}=$ extinction coefficient of cytochrome $\mathrm{C}=$ $2 \cdot 11 \times 10^{4} / \mathrm{M} / \mathrm{cm}$, number of cells $=3.5 \times 10^{6}$ per assay, and light path $=1 \mathrm{~cm}$.

Results are expressed as superoxide production per incubation time rather than per minute because superoxide release from neutrophils is not linear with time. There is a lag time of approximately 60 seconds followed by a gradual rise until a linear rate of change is achieved which is dependent on the stimulus, and finally a termination phase. ${ }^{11-13}$

\section{REPRODUCIBILITY OF THE ASSAY}

This was measured by performing triplicate assays on three occasions, twice using normal neutrophils and once using Crohn's disease neutrophils. The stimulus used for these reproducibility studies was $5 \mu \mathrm{g}$ PMAl. The coefficients of variance of the three assays were $0 \cdot 8 \%, 7 \cdot 3 \%$, and $0 \cdot 8 \%$.

\section{STATISTICAL ANALYSIS}

Results were analysed using the Wilcoxon rank sum test and are expressed as means (SD).

\section{Results}

Superoxide production by normal neutrophils was significantly greater than Crohn's disease neutrophils when PMAl was the stimulus (9.6 $(2 \cdot 2)$ v $8.6(1 \cdot 8) \mathrm{nmol} / 10^{6}$ cells $/ 5$ minutes, $\mathrm{p}=0 \cdot 04)$. PMA2 stimulated far less superoxide production than PMA1, but normal neutrophils still produced more than Crohn's disease neutrophils $\left(1.8(0.8)\right.$ v $0.8(0.77) \mathrm{nmol} / 10^{6}$ cells $/ 5$ minutes, $p=0.00004$ ) (Fig 1).

When phagocytosis was stimulated by $C$ albicans in serum, however, superoxide production by normal neutrophils $\left(4.4(1.5) \mathrm{nmol} / 10^{6}\right.$ 


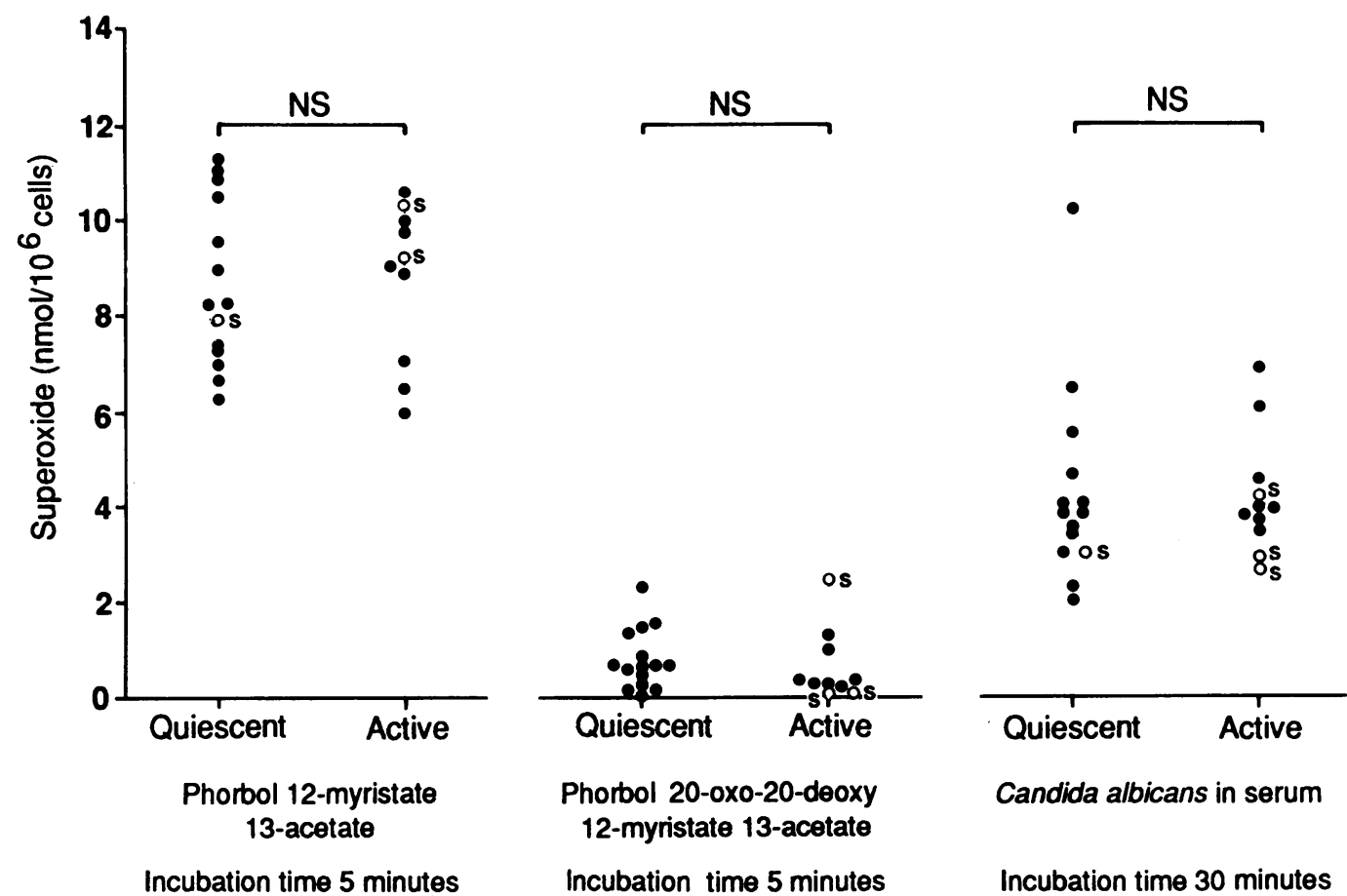

Figure 2: Neutrophil superoxide anion production related to disease activity. $O=$ patient'on steroids.

cells/30 minutes) did not differ significantly from that by Crohn's disease neutrophils (4.3 (1.7) $\mathrm{nmol} / 10^{6}$ cells $/ 30$ minutes). In serum alone both normal and Crohn's disease neutrophils produced superoxide at a rate of $1.2 \mathrm{nmol} / 10^{6}$ cells/30 min (Fig 1).

The results were independent of disease activity (Fig 2).

\section{Discussion}

Superoxide anion production by neutrophils was first shown by Babior et al in $1973 .{ }^{14}$ It is well established that oxygen radicals play an important part in killing phagocytosed microorganisms. ${ }^{1}$ The NADPH-oxidase system can be activated by several pathways. ${ }^{15}$ Phorbol myristate acetate (PMA) is the active component of croton oil and the addition of microgram quantities to a suspension of resting human neutrophils causes a pronounced stimulation of all aspects of cellular oxidative metabolism which are normally associated with phagocytosis. ${ }^{16}$

The importance of an intact NADPH oxidase system is shown by patients with chronic granulomatous disease. They have inherited a defective oxidase which cannot generate sufficient superoxide and hydrogen peroxide, resulting in severe and recurrent bacterial infections. ${ }^{17} 18$ The precise mechanism by which oxygen metabolites kill micro-organisms is uncertain but suggested methods include lipid peroxidation of the cell membrane, inactivation of intracellular enzyme systems, and DNA damage. ${ }^{4}$

Superoxide anions can also react with peroxidase; the aerobic oxidation of NADH by myeloperoxidase requires superoxide. ${ }^{19}$ The killing of C albicans and some bacteria is dependent on this myeloperoxidase system and myeloperoxidase deficient neutrophils do not kill Candida in vitro. ${ }^{20-22}$

These results support the findings of Verspaget et al that superoxide production by Crohn's disease neutrophils is significantly lower than normal when phorbol myristate acetate is the phagocytic stimulus. ${ }^{23-25}$ PMA2 stimulated far less superoxide production than PMA1, but the reasons for this are uncertain. Using a chemiluminescence assay, a technique not specific for superoxide anion, Suematsu et al found no difference between normal and Crohn's disease neutrophils. ${ }^{26}$ Although it is possible that impaired oxidative metabolism accounts for the chronic inflammation, granuloma formation, and impaired microbial killing in Crohn's disease, we found that superoxide production during phagocytosis of $C$ albicans in serum was normal. Thus we have no conclusive evidence that low superoxide production is the cause of the impaired candidacidal activity of Crohn's disease neutrophils which we previously reported. ${ }^{5}$ It is of interest, however, that $C$ albicans is reported to release a substance that selectively impairs the neutrophil respiratory burst without fully inhibiting the NADPH-oxidase system. ${ }^{27}$

Other factors, such as malnutrition or deficiency of micronutrients, can affect neutrophil function in patients with chronic disease. For this reason we investigated patients with quiescent as well as active Crohn's disease; malnutrition is unlikely to be present when patients with inflammatory bowel disease are in remission or in the early stages of an acute attack. ${ }^{28} \mathrm{We}$ found no relation between superoxide production and Crohn's disease activity, so it is unlikely that impaired neutrophil function is a phenomenon secondary to the disease itself. This could be clarified by studying patients with other chronic inflammatory diseases.

PMA-stimulated superoxide anion production by peripheral blood neutrophils is lower than normal in Crohn's disease. Whether this is of primary importance in the pathogenesis of the disease remains to be established. 
1 Babior BM. Oxygen-dependent microbial killing by phagocytes. N Engl ₹ Med 1978; 298: 659-68.

2 Karnavosky ML. The metabolism of leukocytes. Semin Hematol 1968; 5: 156-65.

3 Klebanoff SJ. Oxygen metabolism and the toxic properties of phagocytes. Ann Intern Med 1980; 93: 480-9.

4 Fantone JC, Ward PA. Polymorphonuclear leukocytemediated cell and tissue injury: oxygen metabolites and their relations to human disease. Human Pathol 1985; 16: 973-8.

5 Curran FT, Youngs DJ, Allan RN, Keighley MRB. Candidacidal activity of Crohn's disease neutrophils. Gut 1991; 32: 55-60.

6 McCord JM, Fridovitch I. Superoxide dismutase: an enzymatic function for erythrocuprein (hemocuprein). $\mathcal{f} \mathrm{Biol}$ Chem 1969; 224: 6049-63.

7 McCord JM. Free radicals and inflammation: protection of synovial fluid by superoxide dismutase. Science 1974; 185: 529-31.

8 Harvey RF, Bradshaw JM. A simple index of Crohn's-disease activity. Lancet 1980 ; ii: 514 .

9 Giddings JC, Piovella F, Ricetti M, Jarvis A, Peake IR, Bloom $A L$. Characterization of procoagulant activity produced by cultures of human monocytes and lymphocytes separated in colloidal silica-polyvinyl-pyrrolidone gradients. Clin Lab Haematol 1980; 2: 121-8.

10 Jepson LV, Skottun T. A rapid one-step method for the isolation of human granulocytes from whole blood. Scand $\mathcal{f}$ isolation of human granulocytes

11 Babior BM, Cohen HJ. Measurement of neutrophil function. In: Cline MJ, ed. Leucocyte function. London: Churchill Livingstone, 1981: 1-38.

12 Badwey JA, Karnovsky ML. Production of superoxide by phagocytic leukocytes: a paradigm for stimulus-response phenomena. Curr Top Cell Regul 1986; 28: 183-208.

13 Newburger PE, Chovaniec ME, Cohen HJ. Activity and activation of the granulocyte superoxide-generating system. Blood 1980; 55: 85-92.

14 Babior BM, Kipnes RS, Curnutte JT. Biological defense mechanisms: the production by leukocytes of superoxide, a mechanisms: the production by leukocytes of superoxide, a

15 McPhail LC, Henson PM, Johnston RB. Respiratory burst enzyme in human neutrophils: evidence for multiple mechanisms of ativation 7 Clin Invest 1981; 67: 710-16.

16 DeChatelet LR, Shirley PS, Johnston RB. Effect of phorbol myristate acetate on the oxidative metabolism of human polymorphonuclear leukocytes. Blood 1976; 47: 545-54.
17 Holmes B, Page AR, Good RA. Studies of the metabolic activity of leukocytes from patients with a genetic abnormality of phagocytic function. $\mathcal{F}$ Clin Invest 1967; 46: 142232 .

18 Rosen H, Klebanoff SJ. Chemiluminescence and superoxide production by myeloperoxidase-deficient leukocytes. $\mathcal{F}$ Clin Invest 1976; 58: 50-60.

19 Odajima T, Yamazaki I. Myeloperoxidase of the leukocyte of normal blood. III. The reaction of ferric myeloperoxidase with superoxide anion. Biochim Biophys Acta 1972; 284: 355-9.

20 Larrocha C, de Castro MF, Fontan G, Viloria A, FernandezChacon JL, Jimenez C. Hereditary myeloperoxidase deficiChacon JL, Jimenez C. Hereditary myeloperoxidase defici-

21 Lehrer RI, Cline MJ. Leukocyte myeloperoxidase deficiency and disseminated candidiasis: the role of myeloperoxidase in resistance to Candida infection. F Clin Invest 1969; 48: 147888.

22 Parry MF, Root RK, Metcalf JA, Delaney KK, Kaplow LS, Richar WJ. Myeloperoxidase deficiency: prevalence and clinical significance. Ann Intern Med 1981; 95: 293-301.

23 Verspaget HW, Elmgreen J, Weterman IT, Pena AS, Riis P Lamers CBHW. Impaired activation of the neutrophil oxidative metabolism in chronic inflammatory bowel disease. Scand f Gastroenterol 1986; 21: 1124-30.

24 Verspaget HW, Mieremet-Ooms MAC, Weterman IT, Pena AS. Partial defect of neutrophil oxidative metabolism in Crohn's disease. Gut 1984; 25: 849-53.

25 Verspaget HW, Pena AS, Weterman IT, Lamers CBHW. Diminished neutrophil function in Crohn's disease and ulcerative colitis identified by decreased oxidative metabolism and low superoxide dismutase content. Gut 1988; 29: 223-8.

26 Suematsu M, Suzuki M, Kitahora T, et al. Increased respiratory burst of leukocytes in inflammatory bowel diseases - the analysis of free radical generation by using chemiluminescence probe. F Clin Lab Immunol 1987; 24: 125-8.

27 Smail EH, Melnick DA, Ruggeri R, Diamond RD. A novel natural inhibitor from Candida albicans hyphae causing dissociation of the neutrophil respiratory burst response to dissociation of the neutrophil respiratory burst response to chemotactic peptides from

28 Hill GL, Blackett RL, Pickford IR, Bradley JA. A survey of protein nutrition in patients with inflammatory bowel disease - a rational basis for nutritional therapy. Br $\mathcal{F}$ Surg 1977; 64: 894-6. 